\title{
A Method for the Simultaneous Detection of Vibrio cholerae Strains and Drug-Resistant Genes in their Genome by Real-Time PCR
}

\author{
A. A. Kritskii ${ }^{a}$, N. B. Cheldyshova ${ }^{a}$, S. P. Zadnova ${ }^{a}{ }^{*}$, N. A. Plekhanov ${ }^{a}$, and N. I. Smirnova ${ }^{a}$ \\ ${ }^{a}$ Microbe, Russian Research Antiplague Institute, Saratov, 410005 Russia \\ *e-mail: rusrapi@microbe.ru \\ Received December 26, 2017; in final form, February 14, 2018
}

\begin{abstract}
A method was developed for the simultaneous detection of $V$. cholerae strains and the presence of drug-resistant genes in their genomes by real-time PCR. Resistance to four antibiotics used for cholera treatment (tetracycline, trimethoprim, chloramphenicol and ciprofloxacin) was analyzed. The sensitivity of the panel was $1 \times 10^{3} \mathrm{CFU} / \mathrm{mL}$ for pure cultures, simulated clinical material, and environmental samples. PCR efficiency was confirmed by the analysis of 60 natural $V$. cholerae strains isolated from patients and the environment in different years. It was established that all of the studied $V$. cholerae strains of the O1 serogroup El Tor biovar isolated before 1993 did not contain the tested drug-resistant genes. At the same time, 18 toxigenic clinical strains (90\%) imported within 1993-2010 were characterized by multiple drug resistance; their genomes contained trimethoprim resistance genes $(d f r A 1)$ and chloramphenicol resistance genes $(f l o R)$, and 11 strains additionally contained a tetracycline-resistant gene tet $R$. In addition, nontoxigenic clinical and aqueous $V$. cholerae strains carrying a ciprofloxacin-resistant gene, the qnrVC (qnrVC1) gene, have been detected in the last few years (Kalmykia, 2011-2013).
\end{abstract}

Keywords: drug-resistant genes, multiplex real-time PCR, Vibrio cholerae

DOI: $10.1134 /$ S000368381809003X

\section{INTRODUCTION}

Cholera is a serious, especially dangerous, human infectious disease that can be fatal if left untreated. The causative agents of cholera are toxigenic Vibrio cholerae strains of the $\mathrm{O} 1$ (classical and El Tor biovars) and $\mathrm{O} 139$ serogroups. The seventh cholera pandemic, which was caused by $V$. cholerae strains of $\mathrm{O} 1$ serogroup El Tor biovar, has continued from 1961 to the present. Genetically distinct strains (or atypical El Tor strains) of $V$. cholerae strains of the $\mathrm{O} 1$ serogroup El Tor biovar [1-4] appeared and spread throughout the 1990s. These strains, unlike the typical El Tor bacillus, which caused the onset of the current pandemic, have an increased virulence that is exhibited as more severe manifestations of the disease, and they have high mortality rates. Another important feature of the atypical El Tor strains is multiple resistance to various drugs [5-7].

The atypical El Tor strains not only circulate in cholera endemic regions in Asia, Africa, and the Caribbean countries; they can also be exported to various countries, including Russia. Since 1993, all outbreaks and isolated cases of cholera in the Russian

Abbreviations: AMD—antimicrobial drug; CFU—colony-forming unit; PCR-polymerase chain reaction; Cip-ciprofloxacin; $\mathrm{Cm}$-chloramphenicol; dNTP-deoxynucleoside triphosphate(s); $\mathrm{Tc}$-tetracycline; $\mathrm{Tp}$-trimethoprim.
Federation have been caused by these strains [8]. Single atypical El Tor strains were also isolated from the open reservoirs of our country during monitoring studies. A large number of nontoxigenic $V$. cholerae strains that are capable of causing intestinal infections and contain in some cases additional pathogenic genes with different resistances to antibacterial drugs were isolated from the environment. More than 700 such strains were isolated from 2007 to 2016 [9].

Cholera treatment primarily includes rehydration therapy and, in severe cases, chemotherapy with antibacterial drugs. At the same time, drugs of the tetracycline groups, fluoroquinolones, and trimethoprim are used (the latter is included in coformulated drugs such as sulfamethoxazole/trimethoprim and cotrimoxazole). Fluoroquinolones as reserve drugs are used when strains with multiple drug resistances are detected.

Antimicrobial drugs can reduce the duration and severity of the disease, but their use leads to the emergence of resistant isolates. The problem of the emergence of drug-resistant strains of pathogenic microorganisms is one of the most important issues in modern healthcare. This problem is especially acute in the treatment of especially dangerous quarantine infections, including cholera. According to the WHO, a steady increase in resistance to AMD among pathogenic bacteria, including $V$. cholerae, was detected (WHO Global 
Strategy for Containment of Antimicrobial Resistance:WHO/CDS/CSR/DRS/2001.2 (http://www. who.int/drugresistance/WHO_Global_Strategy_English.pdf?ua=1)). Therefore, rapid access to reliable information about the presence of drug-resistant genes in the genome of the pathogen is required to provide effective therapy for cholera patients and to obtain information about the drug resistance of imported and isolated V. cholerae strains during monitoring studies.

The goal of this study was to develop a method for the simultaneous detection of $V$. cholerae strains of the O1 serogroup and to determine the presence of therapeutically important drug-resistant genes in genomes. For this, multiplex real-time PCR was used.

\section{MATERIALS AND METHODS}

\section{Bacterial Strains and Cultivation Conditions}

Sixty-eight natural $V$. cholerae strains isolated on the territory of Russia and abroad in different years were used in the study (Table 1). In addition, strains of other microorganisms stored in a lyophilized stateEscherichia coli, Klebsiella pneumoniae, Shigella sonnei, Salmonella typhi, Salmonella typhimurium, and Salmonella enteritidis (State Collection of Pathogenic Bacteria of the Russian Antiplague Scientific Research Institute "Microbe", Saratov) - were used. The bacteria were cultivated on LB agar (Sigma, United States) at $37^{\circ} \mathrm{C}$.

\section{Determination of the Sensitivity of Microorganism Cultures to Antimicrobial Drugs}

The sensitivity of cultures to AMD was determined by the disc diffusion method in accordance with Practical Policies 4.2.2495-09, "Determination of the sensitivity of dangerous infectious agents (plague, anthrax, cholera, tularemia, brucellosis, glanders, melioidosis) to antibacterial drugs." Antibiotics produced by HiMedia Laboratories Pvt Limited (India) and Research Center for Pharmacotherapy (Russia) were used. The discs contained the following AMD amounts (per disk): chloramphenicol $30 \mathrm{mg}$, tetracycline $30 \mu \mathrm{g}$, trimethoprim $25 \mu \mathrm{g}$, ciprofloxacin $30 \mu \mathrm{g}$.

\section{DNA Isolation}

Purified DNA was prepared with an Axy Prep Bacterial Genomic DNA Miniprep Kit (Axygen, the United States) according to the manufacturer's protocol. Before isolation, the bacterial suspensions were treated with a $0.01 \%$ sodium merthiolate solution (Sigma-Aldrich, United States) and heated at $56^{\circ} \mathrm{C}$ for $30 \mathrm{~min}$.

\section{Polymerase Chain Reaction}

PCR was performed with a Rotor-Gene Q 5plex (Qiagen Inc, GMBH, Germany) amplifier with primers and TaqMan ${ }^{\circledR}$ probes synthesized by Synthol (Russia).

\section{RESULTS AND DISCUSSION \\ Determination of Toxigenicity \\ of V. cholerae Strains Used in the Study}

In the first stage of the study, all V. cholerae biovar El Tor strains were tested with real-time PCR for the presence of the $\operatorname{ctx} A$ gene, which encodes the toxic Asubunit of cholera toxin. The primers and probe for the fragment of the ctxA gene were calculated by us in advance [10]. Based on the study results, we revealed 34 of $60 \mathrm{~V}$. cholerae biovar El Tor strains containing the $\operatorname{ctx} A$ gene, i.e. toxigenic. At the same time, 26 strains isolated from human and from the environment did not carry the $\operatorname{ctx} A$ gene and were nontoxigenic (Table 1).

\section{Determination of the Sensitivity of V. cholerae Strains to Antimicrobial Drugs}

The sensitivity of all studied strains to the most commonly drugs used for the treatment of cholera AMD (chloramphenicol, tetracycline, trimethoprim, ciprofloxacin) was later determined by the disc diffusion method. The analysis demonstrated that 20 typical strains (91\%) of those isolated in 1966-1988 were sensitive to the tested AMD. Two nontoxigenic V. cholerae strains, M1399 and M1400, were the exception; they were isolated from the environment in Astrakhan in 1982 and proved to be resistant to ciprofloxacin (Table 1).

According to the literature, $V$. cholerae biovar El Tor strains with multiple $(>3)$ drug resistances were registered in the 1990s [11, 12]. Indeed, according to the obtained information, the toxigenic $V$. cholerae biovar El Tor strains imported into Krasnodar, Kazan and Dagestan in 1993 were resistant to tetracycline, chloramphenicol, and trimethoprim. It is interesting that the clinical strains that were imported later, including the modern isolates, were already sensitive to tetracycline. The only exception was strain M1269 (Magnitogorsk, 1994), which was resistant to this antibiotic. Strains isolated in 1993-2010 were also resistant to trimethoprim and chloramphenicol. Two strains, M1293 and M1295 (Dagestan, 1994), were an exception; these strains were resistant to trimethoprim but sensitive to levomycetin (chloramphenicol). It should be noted that the cholera in Dagestan in 1994 was caused by $V$. cholerae biovar El Tor strains with a different sensitivity to chloramphenicol. One group of strains (M1286, M1287, M1288) was resistant to this antibiotic, while the other (M1293, M1295) was sensitive (Table 1). Perhaps this was due to the fact that the cholera in Dagestan in 1994 was caused by strains imported by pilgrims from different endemic territories [13]. 
Table 1. Sensitivity to antibacterial preparations and the occurrence of drug-resistant genes in $V$. cholerae strains of the O1 serogroup El Tor biovar as determined by PCR

\begin{tabular}{|c|c|c|c|c|c|c|c|c|c|c|c|}
\hline \multirow{2}{*}{$\begin{array}{c}\text { Strain } \\
\text { identification }\end{array}$} & \multirow{2}{*}{$\begin{array}{c}\text { Place, year and } \\
\text { source of isolation }\end{array}$} & \multirow{2}{*}{$\begin{array}{l}\text { The presence } \\
\text { of the } \operatorname{ctx} A \text { gene }\end{array}$} & \multicolumn{4}{|c|}{ Sensitivity to AMD } & \multicolumn{5}{|c|}{ Presence of drug-resistant genes } \\
\hline & & & Tc & Cip & $\mathrm{Cm}$ & $\mathrm{Tp}$ & $r f b E$ & tet $R$ & \begin{tabular}{|c|}
$q n r V C$ \\
$(q n r V C 1)$
\end{tabular} & floR & $d f r A 1$ \\
\hline ATCC14033 & Sinai, 1910, human & - & $\mathrm{S}$ & $\mathrm{S}$ & $\mathrm{S}$ & $\mathrm{S}$ & + & - & - & - & - \\
\hline MAK757 & $\begin{array}{l}\text { Celebes Island, 1937, } \\
\text { human }\end{array}$ & + & $\mathrm{S}$ & $\mathrm{S}$ & S & $\mathrm{S}$ & + & - & - & - & - \\
\hline CW6 & India, 1966, water & + & $\mathrm{S}$ & $\mathrm{S}$ & $\mathrm{S}$ & $\mathrm{S}$ & + & - & - & - & - \\
\hline 34 Qayum & $\begin{array}{l}\text { Afghanistan, 1966, } \\
\text { human }\end{array}$ & - & $\mathrm{S}$ & $\mathrm{S}$ & S & $\mathrm{S}$ & + & - & - & - & - \\
\hline $\begin{array}{l}\text { M818, M886, } \\
\text { M1051 }\end{array}$ & $\begin{array}{l}\text { RF, Astrakhan, 1970, } \\
\text { human }\end{array}$ & + & $\mathrm{S}$ & $\mathrm{S}$ & $\mathrm{S}$ & $\mathrm{S}$ & + & - & - & - & - \\
\hline M642 & $\begin{array}{l}\text { RF, Astrakhan, 1975, } \\
\text { human }\end{array}$ & + & $\mathrm{S}$ & $\mathrm{S}$ & $\mathrm{S}$ & $\mathrm{S}$ & + & - & - & - & - \\
\hline M1394 & $\begin{array}{l}\text { RF, Kalmykia, 1979, } \\
\text { water }\end{array}$ & - & $\mathrm{S}$ & $\mathrm{S}$ & $\mathrm{S}$ & $\mathrm{S}$ & + & - & - & - & - \\
\hline $\begin{array}{l}\text { M1335, M1397, } \\
\text { M1398 }\end{array}$ & $\begin{array}{l}\text { RF, Astrakhan, 1981, } \\
\text { water }\end{array}$ & - & $\mathrm{S}$ & $\mathrm{S}$ & $\mathrm{S}$ & $\mathrm{S}$ & + & - & - & - & - \\
\hline M1399, M1400 & $\begin{array}{l}\text { RF, Astrakhan, 1982, } \\
\text { water }\end{array}$ & - & $\mathrm{S}$ & $\mathrm{R}$ & $\mathrm{S}$ & $\mathrm{S}$ & + & - & + & - & - \\
\hline M1401 & $\begin{array}{l}\text { RF, Astrakhan, 1982, } \\
\text { water }\end{array}$ & - & $\mathrm{S}$ & $\mathrm{S}$ & $\mathrm{S}$ & $\mathrm{S}$ & + & - & - & - & - \\
\hline $\begin{array}{l}25,33,95,113 \\
121,317\end{array}$ & $\begin{array}{l}\text { Guinea, 1986, } \\
\text { human }\end{array}$ & + & $\mathrm{S}$ & $\mathrm{S}$ & $\mathrm{S}$ & $\mathrm{S}$ & + & - & - & - & - \\
\hline 99,190 & Guinea, 1986, water & + & $\mathrm{S}$ & $\mathrm{S}$ & $\mathrm{S}$ & $\mathrm{S}$ & + & - & - & - & - \\
\hline M1402 & $\begin{array}{l}\text { RF, Astrakhan, 1988, } \\
\text { water }\end{array}$ & - & $\mathrm{S}$ & $\mathrm{S}$ & S & $\mathrm{S}$ & + & - & - & - & - \\
\hline $\begin{array}{l}\text { M1264, M1272, } \\
\text { M1298, M1299 }\end{array}$ & $\begin{array}{l}\text { RF, Krasnodar, } \\
\text { 1993, human }\end{array}$ & + & $\mathrm{R}$ & $\mathrm{S}$ & $\mathrm{R}$ & $\mathrm{R}$ & + & + & - & + & + \\
\hline M1270, M1271 & $\begin{array}{l}\text { RF, Kazan, 1993, } \\
\text { human }\end{array}$ & + & $\mathrm{R}$ & $\mathrm{S}$ & $\mathrm{R}$ & $\mathrm{R}$ & + & + & - & + & + \\
\hline $\begin{array}{l}\text { M1275, M1278, } \\
\text { M1279, M1297 }\end{array}$ & $\begin{array}{l}\text { RF, Dagestan, 1993, } \\
\text { human }\end{array}$ & + & $\mathrm{R}$ & $\mathrm{S}$ & $\mathrm{R}$ & $\mathrm{R}$ & + & + & - & + & + \\
\hline M1295, M1293 & $\begin{array}{l}\text { RF, Dagestan, 1994, } \\
\text { human }\end{array}$ & + & $\mathrm{S}$ & $\mathrm{S}$ & $\mathrm{S}$ & $\mathrm{R}$ & + & - & - & - & + \\
\hline $\begin{array}{l}\text { M1286, M1287, } \\
\text { M1288, }\end{array}$ & $\begin{array}{l}\text { RF, Dagestan, 1994, } \\
\text { human }\end{array}$ & + & $\mathrm{S}$ & $\mathrm{S}$ & $\mathrm{R}$ & $\mathrm{R}$ & + & - & - & + & + \\
\hline M1269 & $\begin{array}{l}\text { RF, Magnitogorsk, } \\
\text { 1994, human }\end{array}$ & + & $\mathrm{R}$ & $\mathrm{S}$ & $\mathrm{R}$ & $\mathrm{R}$ & + & + & - & + & + \\
\hline P17644 & $\begin{array}{l}\text { Russia, Achinsk, } \\
\text { 1997, human }\end{array}$ & + & $\mathrm{S}$ & $\mathrm{S}$ & $\mathrm{R}$ & $\mathrm{R}$ & + & - & - & + & + \\
\hline $\begin{array}{l}\text { M1318, M1329, } \\
\text { M1330, M1336 }\end{array}$ & $\begin{array}{l}\text { RF, Astrakhan, } \\
\text { 1988-2000, water }\end{array}$ & - & $\mathrm{S}$ & $\mathrm{S}$ & $\mathrm{S}$ & $\mathrm{S}$ & + & - & - & - & - \\
\hline $\begin{array}{l}\text { M1384, M1385, } \\
\text { M1386 }\end{array}$ & $\begin{array}{l}\text { RF, Astrakhan, 2001, } \\
\text { water }\end{array}$ & - & $\mathrm{S}$ & $\mathrm{S}$ & S & $\mathrm{S}$ & + & - & - & - & - \\
\hline M1427 & $\begin{array}{l}\text { RF, Astrakhan, 2003, } \\
\text { water }\end{array}$ & - & $\mathrm{S}$ & $\mathrm{S}$ & $\mathrm{S}$ & $\mathrm{S}$ & + & - & - & - & - \\
\hline M1429 & $\begin{array}{l}\text { RF, Bashkiria, 2004, } \\
\text { human }\end{array}$ & + & $\mathrm{S}$ & $\mathrm{S}$ & $\mathrm{R}$ & $\mathrm{R}$ & + & - & - & + & + \\
\hline
\end{tabular}


Table 1. (Contd.)

\begin{tabular}{|c|c|c|c|c|c|c|c|c|c|c|c|}
\hline \multirow{2}{*}{$\begin{array}{c}\text { Strain } \\
\text { identification }\end{array}$} & \multirow{2}{*}{$\begin{array}{l}\text { Place, year and } \\
\text { source of isolation }\end{array}$} & \multirow{2}{*}{$\begin{array}{c}\text { The presence } \\
\text { of the } \operatorname{ctx} A \text { gene }\end{array}$} & \multicolumn{4}{|c|}{ Sensitivity to AMD } & \multicolumn{5}{|c|}{ Presence of drug-resistant genes } \\
\hline & & & Tc & Cip & $\mathrm{Cm}$ & $\mathrm{Tp}$ & $r f b E$ & tet $R$ & $\begin{array}{c}q n r V C \\
(q n r V C 1)\end{array}$ & floR & $d f r A 1$ \\
\hline $\begin{array}{l}\text { P18778, P18793, } \\
\text { P18796, P18806 }\end{array}$ & $\begin{array}{l}\text { RF, Rostov-on-Don, } \\
\text { 2005, human }\end{array}$ & - & $\mathrm{S}$ & $\mathrm{S}$ & $\mathrm{S}$ & $\mathrm{S}$ & + & - & - & - & - \\
\hline P18899 & $\begin{array}{l}\text { RF, Murmansk, } \\
\text { 2006, human }\end{array}$ & + & $\mathrm{S}$ & S & $\mathrm{R}$ & $\mathrm{R}$ & + & - & - & + & + \\
\hline L3226 & $\begin{array}{l}\text { RF, Moscow, 2010, } \\
\text { human }\end{array}$ & + & $\mathrm{S}$ & S & $\mathrm{R}$ & $\mathrm{R}$ & + & - & - & + & + \\
\hline M1501 & $\begin{array}{l}\text { RF, Kalmykia, 2011, } \\
\text { human }\end{array}$ & - & $\mathrm{S}$ & $\mathrm{R}$ & S & $\mathrm{S}$ & + & - & + & - & - \\
\hline M1518 & $\begin{array}{l}\text { RF, Kalmykia, 2012, } \\
\text { water }\end{array}$ & - & $\mathrm{S}$ & $\mathrm{R}$ & $\mathrm{S}$ & S & + & - & + & - & - \\
\hline M1524 & $\begin{array}{l}\text { RF, Kalmykia, 2013, } \\
\text { water }\end{array}$ & - & $\mathrm{S}$ & $\mathrm{R}$ & $\mathrm{S}$ & S & + & - & + & - & - \\
\hline M1522 & $\begin{array}{l}\text { RF, Kalmykia, 2014, } \\
\text { water }\end{array}$ & - & $\mathrm{S}$ & $\mathrm{S}$ & $S$ & $\mathrm{~S}$ & + & - & - & - & - \\
\hline
\end{tabular}

All nontoxigenic strains isolated from both the environment and patients in 1998-2014 were sensitive to the studied AMD. However, in Kalmykia in 20112013 , strains resistant to second-generation fluoroquinolone-ciprofloxacin were isolated (see Table 1).

\section{Selection of DNA Target Sequences and the Development of an Amplification Protocol}

Several mechanisms of the formation of drug resistance in bacteria have now been described. Such structures as plasmids, insertion sequences (IS elements), transposons, and integrins with gene cassettes are involved in the distribution of drug-resistant genes. An important role belongs to other complex organized structures-integrative and conjugative elements (ICEs) and integrative mobilized elements (IMEs) and genomic islands. The causative agent of cholera constantly acquires drug-resistant genes via the introduction of mobile genetic elements. In its genome, plasmids, first and second class integrins, as well as SXT elements (SulfamethoXazole-Trimethoprim), were detected [14, 15]. In this case, the genes determining resistance to a particular drug can often be part of different genetic elements. For example, the $d f r A(d f r A l)$ gene, which determines the resistance to trimethoprim/sulfamethoxazole, was detected in the SXT element, IncC plasmids, and integrins of the first and second classes [16, 17]. A cassette with $q n r V C$ genes providing resistance to ciprofloxacin can be localized both on plasmids and on SXT element $[18,19]$.

An adequate choice of cholera treatment can only be made based on a preliminary determination of the sensitivity of isolated cholera strains to AMD. We designed a set of primers and probes for real-time PCR for the simultaneous detection of $V$. cholerae strains and the determination of drug-resistant genes in their genome. With the use of the real-time regime, we planned to reduce the time to determine drugresistant genes to $3-4 \mathrm{~h}$, simultaneously identifying all four resistant genes. For comparison, analysis by the disc method, E-test method, and dilution methods in a liquid nutrient medium or in agar requires $18-48 \mathrm{~h}$, and the use of singleplex PCR test systems with electrophoretic detection of resistance to only one antibiotic requires 5-8 h [20]. It should be noted that the probability of false positive results in our case is minimized (nucleotide sequences of more than 100 strains of $V$. cholerae were analyzed for the design of primers and probes, and specific primers and probes, as well as PCR conditions, were selected). In addition, we reduced the possibility of contamination of the PCR mixture by excluding the electrophoretic DNA separation step from the determination.

The site of the $r f b E$ gene ( $v c 0244$ ) from the $r f b$ cluster, which encodes the biosynthesis of O1-antigen [21], was selected as the target for pathogen detection. This made it possible to detect $V$. cholerae strains of the O1 serogroup. We decided not identify the bacillus of the 0139 serogroup, which caused cholera outbreaks in 1992-1993, since strains of this serogroup are not imported into Russia; they cause local outbreaks only in India.

To determine the resistance of strains to drugs, AMDs are most often used to treat cholera; namely, tetracycline, trimethoprim, chloramphenicol (levomycetin), and ciprofloxacin were chosen. the tet $R$ gene was chosen as the DNA target encoding tetracycline resistance, the site of the floR gene was selected to detect 
Table 2. Primers and hydrolysis probes constructed to detect drug-resistant genes

\begin{tabular}{|c|c|c|}
\hline Primer, probe & Sequence $5^{\prime} \rightarrow 3^{\prime}$ & Detection channel \\
\hline $\begin{array}{l}\text { tet } R-F \\
\text { tet } R-R \\
\text { tet } R \text {-probe }\end{array}$ & $\begin{array}{l}\text { TCAGTGATAAAGTGTCAAGCA } \\
\text { AGTTTGCGTGTCGTCAG } \\
\text { (Cy5)-TTGCAGCCGAATACAGTGATCCGT-(BHQ2) }\end{array}$ & Red \\
\hline $\begin{array}{l}\text { qnrVC1-F } \\
q n r V C 1-R \\
q n r V C 1-\text { probe }\end{array}$ & $\begin{array}{l}\text { CAAACCTCCGCGATACACAA } \\
\text { CGCATTCTCTGAACTCGATACC } \\
\text { (R6G)-TGTAGACTGTTCTTTCATTGAACGAGGTGA-(BHQ1) }\end{array}$ & Yellow \\
\hline $\begin{array}{l}d f r A 1-F \\
d f r A 1-R \\
d f r A 1-\text { probe }\end{array}$ & $\begin{array}{l}\text { GAATGGAGTTATCGGGAATGG } \\
\text { TCTTGCGTCCAACCAACA } \\
\text { (ROX)-GGAGTGCCAAAGGTGAACAGCT-(BHQ2) }\end{array}$ & Orange \\
\hline $\begin{array}{l}\text { floR }-F \\
\text { floR-R } \\
\text { floR-probe }\end{array}$ & $\begin{array}{l}\text { GGGTTTACACTGTCGGCTTTA } \\
\text { TTCCGCTTGGCCTATGA } \\
\text { (Cy5,5)-CGGTATGGGCACCTTCTTCGTCTT-(RTQ2) } \\
\end{array}$ & Crimson \\
\hline $\begin{array}{l}r f b E-F \\
r f b E-R \\
r f b E \text {-probe }\end{array}$ & $\begin{array}{l}\text { ACTTATGTTGCCTCGGTTAATA } \\
\text { GTAGAGACTCACCTTCGATTTC } \\
\text { (FAM)- ATAGTCCAGTGTGGTGCGTTACCC-(BHQ1) }\end{array}$ & Green \\
\hline
\end{tabular}

chloramphenicol resistance, $d r f A l$ was chosen to detect trimethoprim resistance, and $q n r V C$ ( $q n r V C 1)$ was used to detect fluoroquinolones resistance.

A pair of primers and a hydrolysis probe were calculated for each gene with the IDPrimerQuest online program. During the selection of primers and probes, special attention was paid to their compliance with the requirements for the design of oligonucleotides for TaqMan ${ }^{\circledR}$ systems. In total, five pairs of primers and probes with detection on five different channels were calculated (Table 2).

The PCR mix for the developed amplification variant contained the following components: $8 \mathrm{pmol} / \mu \mathrm{L}$ of each primer, $4 \mathrm{pmol} / \mu \mathrm{L}$ probe; 1.5 units. Taq polymerase; $2.5 \mu \mathrm{L}$ of 10 -fold PCR buffer ( $\mathrm{pH} 8.4$ ), $25 \mathrm{mM}$ $\mathrm{MgCl}_{2}$ solution, $2 \mathrm{mM}$ dNTP (all components produced by Synthol, Russia); and $5 \mu$ L DNA sample and deionized water up to a final volume of $25 \mu \mathrm{L}$.

The amplification protocol included the following steps: 1 cycle at $95^{\circ} \mathrm{C}$ for $5 \mathrm{~min} ; 35$ cycles at $95^{\circ} \mathrm{C}$ for $15 \mathrm{~s}$ and $60^{\circ} \mathrm{C}$ for $60 \mathrm{~s}$ with the detection of a fluorescent signal during the annealing stage simultaneously on five channels in one tube. Table 2 shows that the amplification product was detected on an individual channel for each gene: tetR-Red channel, $d f r A$ $(d f r A l)$-Orange, floR-Crimson, qnrVC (qnrVCl)Yellow, and $r f b E$-Green channel.

Thus, the proposed method was designed for the simultaneous detection of $V$. cholerae strains of the O1 serogroup and for the identification of therapeutically important resistant genes in their genome by real-time PCR. The developed method uses five sets of specific primers and probes.

\section{Determination of Specificity and Effectiveness of the Developed Primers and Probes Sets}

Five toxigenic $V$. cholerae strains of the $\mathrm{O} 1$ serogroup classical biovar were used (M29, 16002B, Dacca 3, Dacca 35, B1307), $V$. cholerae O139 (P16064), two $V$. cholerae strains neO1/neO139 (1332-69, 13030), two E. coli strains (M17 and 6), K. pneumoniae strain 1, Shigella sonnei (ATCC 25931), Salmonella typhi (ATCC H901), Salmonella typhimurium (ATCC 14028), and Salmonella enteritidis (WHO) were used to assess the specificity of primers and probes (Table 3). It is known that the classical biovar strains do not contain drug-resistant genes [15]. Indeed, only the $r f b E$ gene was detected in these strains, and all other tested drug-resistant genes were absent (Table 3).

At the same time, negative PCR results were obtained for $V$. cholerae strains of neO1/neO139 serogroup, E. coli, K. pneumoniae, Salmonella enteritidis, S. typhimurium, S. typhi, and Shigella sonnei for the determination of the site of the $r f b E$ gene. These results confirm the specificity of the selected primers and probes. V. cholerae strain O139 contained only the floR gene. The obtained data correspond to the literature data, according to which the toxigenic strains of the O139 serogroup contain the SXT element, which simultaneously determines resistance to four AMDs: sulfamethoxazole (sulII), trimethoprim ( $f$ fr 18$)$, chloramphenicol (floR), and streptomycin (strB) [22]. However, the trimethoprim-resistant gene in strains of the O139 serogroup ( $d f r 18)$ had a structure different from the $d f r A 1$ gene of the El Tor bacillus, and this allele was not detected by our system. 
Table 3. Specificity of the developed PCR

\begin{tabular}{|c|c|c|c|c|c|c|}
\hline \multirow[b]{2}{*}{ Strain } & \multirow{2}{*}{$\begin{array}{l}\text { Place, year and source } \\
\text { of strain isolation }\end{array}$} & \multicolumn{5}{|c|}{ Presence of drug-resistant genes } \\
\hline & & $r f b E$ & tet $R$ & $\begin{array}{c}q n r V C \\
(q n r V C 1)\end{array}$ & floR & $d f r A 1$ \\
\hline V. cholerae $\mathrm{O} 1 \mathrm{M} 29$ & RF, Astrakhan, 1942, human & + & - & - & - & - \\
\hline V. cholerae $\mathrm{O} 116002 \mathrm{~B}$ & India, 1944, human & + & - & - & - & - \\
\hline V. cholerae O1 Dacca 3, Dacca 35 & Pakistan, 1958, human & + & - & - & - & - \\
\hline V. cholerae $\mathrm{O} 1 \mathrm{~B} 1307$ & Pakistan, 1964, human & + & - & - & - & - \\
\hline V. cholerae $\mathrm{O} 139 \mathrm{P} 16064$ & RF, Azov, 1993, human & - & - & - & + & - \\
\hline V. cholerae nonO1/nonO139 1332-69 & Sudan, 1967, u/k & - & - & - & - & - \\
\hline V. cholerae nonO1/nonO139 13030 & RF, Astrakhan, 1976, u/k & - & - & - & - & - \\
\hline Salmonella typhi ATCC H901 & $\mathrm{RF}, 1918, \mathrm{u} / \mathrm{k}$ & - & - & - & - & - \\
\hline S. enteritidis WHO & $\mathrm{U} / \mathrm{k}, 1956, \mathrm{u} / \mathrm{k}$ & - & - & - & - & - \\
\hline S. typhimurium ATCC 14028 & Unknown & - & - & - & - & - \\
\hline E. coli $\mathrm{M} 17$ & RF, Saratov, u/k, water & - & - & - & - & - \\
\hline E. coli 6 & RF, Saratov, 2016, human & - & + & - & - & - \\
\hline K. pneumoniae 1 & RF, Saratov, 2016, human & - & + & - & - & + \\
\hline Shigella sonnei ATCC 25931 & Panama, $\mathrm{u} / \mathrm{k}$, human & - & - & - & - & - \\
\hline
\end{tabular}

$\mathrm{U} / \mathrm{k}$, source is unknown. Designations of drug-resistant genes are given in Table 1.

The regions of the floR and qnrVC (qnrVC1) genes in the used $V$. cholerae strains of neO1/neO139 serogroup, E. coli, K. pneumoniae, Salmonella enteritidis, $S$. typhimurium, $S$. typhi, and Shigella sonnei were not detected. However, tetR and $d f r A 1$ genes were detected in the genome of the K. pneumoniae 1 strain, and the tet $R$ gene was identified in the genome of the $E$. coli strain 6 (Table 3). First, the obtained data indicated a wide distribution of tetracycline- and trimethoprimresistant genes among various microorganism groups. Second, they demonstrated that the designed primers and probes for the detection of regions of the tet $R$ and $d f r A 1$ genes can be used to detect these genes, not only in $V$. cholerae but also in other microorganisms.

The sensitivity of the analysis of the pure culture of $V$. cholerae strains with a constructed panel was $1 \times 10^{3} \mathrm{CFU} / \mathrm{mL}$.

The developed kit was later tested with 60 natural V. cholerae strains of the O1 serogroup El Tor biovar (Table 1). Among them, two strains were related to prepandemics (ATCC 14033 and MAK 757), 12 were related to toxigenic typical strains isolated at the beginning and initial years of the current pandemic (1966-1986), and 20 were related to toxigenic strains of atypical El Tor strains imported in 1993-2010. Another 26 strains isolated from both humans and water from environmental reservoirs were atoxigenic (Table 1).

Clinical $V$. cholerae strains of the $\mathrm{O} 1$ serogroup El Tor biovar isolated before 1993 did not carry the floR, dfrAl, qnrVC (qnrVC1), or tetR genes (see Table 1). The obtained PCR results correspond to the data from the disc diffusion method and the literature data showing high sensitivity of the prepandemic and clinical $V$. cholerae $\mathrm{O} 1$ biovar El Tor, isolated during this period of the current pandemic [11, 23] to the AMD. At the same time, $88 \%$ (14 of 16) of the clinical V. cholerae strains of biovar El Tor isolated after 1993 carried floR and $d f r A l$ genes (possibly due to the presence of the SXT element in the genome). Figure 1 shows the results of the determination of the floR gene in some typical and atypical El Tor strains. It can be seen that this gene was found in strains M1264, M1279, and L3226 (signal above the threshold), and it was not detected in strains M818, 113, M1293, P18796, or M1501 (signal below the threshold).

In 11 of the 16 strains isolated after 1993, the tet $R$ gene was also detected with the developed PCR system (see Table 1). However, atypical El Tor strains isolated during the modern period (2004-2010) did not carry this gene.

All nontoxigenic strains were deprived of the floR, $d f r A 1$, and tetR genes. At the same time, the qnrVC ( $q n r V C 1)$ gene, which is responsible for ciprofloxacin resistance, was detected in the genome of two strains isolated from river water in Astrakhan in 1982. This gene was also detected in one clinical (2011) and two aquatic (2012-2013) strains isolated in the modern period in Kalmykia (Table 1).

In addition, we studied the use of a constructed kit to analyze samples contaminated by the cholera pathogen from the environment (river water, food products) and samples simulating clinical material (1\% liquid potato starch). All samples, including environmental 


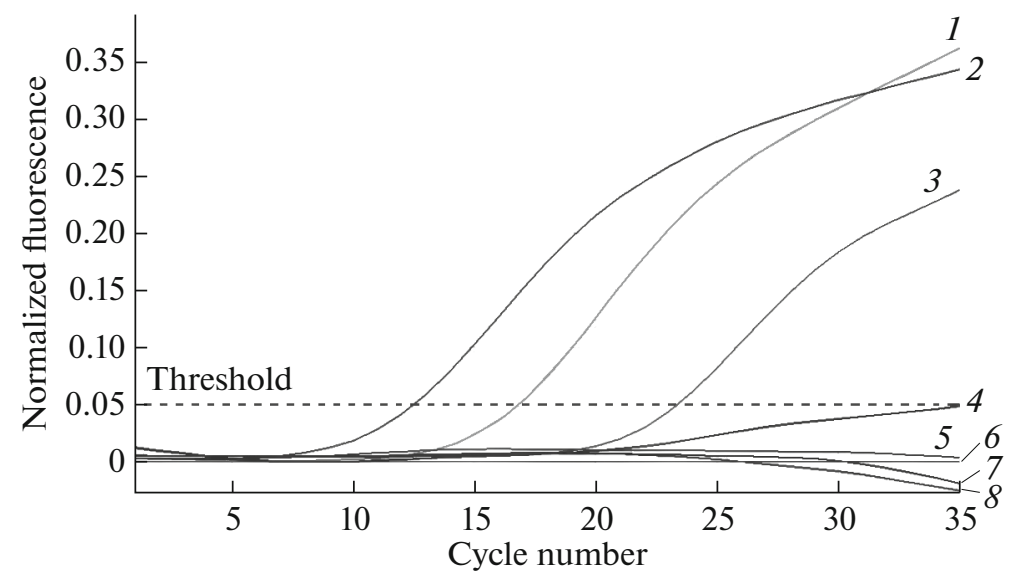

Fig 1. Accumulation of the fluorescent signal of amplified product (floR gene) in $V$. cholerae strains (detected by Crimson channel): 1-M1264, 2-M1279, 3-L3226, 4-M818, 5-113, 6-M1293, 7-P18796, 8-M1501.

samples, were sterilized by autoclaving at $126 \pm 2^{\circ} \mathrm{C}$. The samples contained $V$. cholerae suspensions in a concentration from $1 \times 10^{9}$ to $1 \times 10^{2} \mathrm{CFU} / \mathrm{mL}$. As a result, it was found that the kit sensitivity for these samples was $1 \times 10^{3} \mathrm{CFU} / \mathrm{mL}$ (data not shown). Taking into account that the clinical material and environmental samples could be contaminated with other microorganisms containing AMD-resistant genes, the proposed variant of PCR should be performed only for colonies that may contain cholera bacilli.

\section{CONCLUSIONS}

Thus, a multiplex real-time PCR method was developed for the simultaneous detection of $V$. cholerae strains of the $\mathrm{O} 1$ serogroup and the determination of the presence of resistant genes to four drugs used to treat cholera (chloramphenicol, trimethoprim, tetracycline, and ciprofloxacin) in their genomes. The sensitivity of the constructed set of primers and probes is $1 \times 10^{3} \mathrm{CFU} / \mathrm{mL}$. The effectiveness of the developed method was confirmed via the analysis of 60 natural $V$. cholerae strains isolated over different years from people and from the environment.

\section{REFERENCES}

1. Nair, G.B., Faruque, S.M., Bhuiyan, N.A., et al., New variants of Vibrio cholerae $\mathrm{O} 1$ biotype El Tor with attributes of the classical biotype from hospitalized patients with acute diarrhea in Bangladesh, J. Clin. Microbiol., 2002, vol. 40, no. 9, pp. 3296-3299. doi 10.1128/ jcm.40.9.3296-3299.2002

2. Nair, G.B., Qadri, F., Holmgren, J., et al., Cholera due to altered El Tor strains of Vibrio cholerae $\mathrm{O} 1$ in Bangladesh, J. Clin. Microbiol., 2006, vol. 44, no. 11, pp. 4211-4213. doi 10.1128/jcm.01304-06

3. Safa, A., Nair, G.B., and Kong, R.Y., Evolution of new variants of Vibrio cholerae O1, Trends Microbiol., 2010, vol. 18, pp. 46-54. doi 10.1016/j.tim.2009.10.003
4. Mutreja, A., Kim, D.W., Thomson, N.R., et al., Evidence for several waves of global transmission within the seventh cholera pandemic, Nature, 2011, vol. 477, no. 7365, pp. 462-465.

5. Taneja, N., Mishra, A., Sangar, G., et al., Outbreaks caused by new variants of Vibrio cholerae $\mathrm{O} 1 \mathrm{El}$ Tor, India, Emerg. Infect. Dis., 2009, vol. 15, no. 2, pp. 352354. doi 10.3201/eid1502.080943

6. Grim, C.J., Choi, J., Chun, J., et al., Occurrence of the Vibrio cholerae seventh pandemic VSP-I island and a new variant, $O M I C$, vol. 14 , no. 1 , pp. $1-7$. doi 10.1089/omi.2009.0087

7. Carignan, B.M., Brumfield, K.D., and Son, M.S., Single nucleotide polymorphisms in regulator-encoding genes have an additive effect on virulence gene expression in a Vibrio cholerae clinical isolate, $m$ Sphere, vol. 1, no. 5. e00253-16. doi 10.1128/mSphere.00253-16

8. Smirnova, N.I., Goryaev, A.A., Zadnova, S.P., et al., Genetic characterization of clinical Vibrio cholerae strains imported into the territory of the Russian Federation in the present period, Zh. Mikrobiol. Epidemiol. Immunobiol., 2011, no. 3, pp. 3-10.

9. Moskvitina, E.A., Tyuleneva, E.G., Samorodova, A.V., et al., The epidemiological situation with cholera in the world and Russia in 2007-2016, forecast for 2017, Probl. Osobo Opasnykh Infekts., 2017, vol. 1, pp. 13-20. doi 10.21055/0370-1069-2017-1-13-20

10. Kritskii, A.A., Cheldyshova, N.B., Tuchkov, I.V., and Smirnova, N.I., Development of an algorithm determining the level of expression of $\operatorname{ctx} A$ and toxR genes of Vibrio cholerae by RT-PCR with real-time hybridization-fluorescent recording of results, Probl. Osobo Opasnykh Infekts., 2017, no. 3, pp. 53-57. doi 10.21055/03701069-2017-3-53-57

11. Osin, A.V., Nefedov, K.S., Eroshenko, G.A., and Smirnova, N.I., Comparative genomic analysis of Vibrio cholerae El Tor preseventh and seventh pandemic strains isolated in various periods, Russ. J. Genet., 2005, vol. 41, no. 1, pp. 44-52.

12. Yamamoto, T., Nair, G.B., Albert, M.J., et al., In vitro susceptibility of Vibrio cholerae $\mathrm{O} 1$ and $\mathrm{O} 139$ to antimicrobial agents and appearance of drug resistance plas- 
mids in Vibrio cholerae, in Proceedings of the 30th USJapan Joint Conference on Cholera. US-Japan Cooperative Medical Science Program for Cholera and Related Diarrheal Diseases Panel, Fukuara, Japan, 1994, pp. 52-57.

13. Onishchenko, G.G., Belyaev, E.N., Moskvitina, E.A., Rezaikin, V.I., Lomov, Yu.M., and Medinskii, G.M., Kholera $v$ Dagestane: proshloe i nastoyashchee (Cholera in Dagestan: The Past and The Present), Rostov-onDon, Poligraf, 1995.

14. Il'ina, T.S., Mobile ISCR-elements: structure, function, and role in the creation, building, and propagation of blocks of bacterial genes of multiple resistance to antibiotics, Mol. Genet. Mikrobiol. Virusol., 2012, no. 4, pp. 3-13.

15. Kitaoka, M., Miyata, S.T., Unterweger, D., and Pukatzki, S., Antibiotic resistance mechanisms of Vibrio cholerae, J. Med. Microbiol., 2011, vol. 60, no. 4, pp. 397-407. doi 10.1099/jmm.0.023051-0

16. Dalsgaard, A., Forslund, A., Sandvang, D., et al., Vibrio cholerae $\mathrm{O} 1$ outbreak isolates in Mozambique and South Africa in 1998 are multiple-drug resistant, contain the SXT element and the aadA2 gene located on class 1 integrons, J. Antimicrob. Chemother., 2001, vol. 48, no. 6, pp. 827-838. doi 10.1093/jac/48.6.827

17. Pugliese, N., Maimone, F., Scrascia, M., et al., SXTrelated integrating conjugative element and IncC plasmids in Vibrio cholerae O1 strains in Eastern Africa, J. Antimicrob. Chemother., 2009, vol. 63, no. 3, pp. 438442. doi $10.1093 / \mathrm{jac} / \mathrm{dkn} 542$
18. Chattaway, M.A., Aboderin, A.O., Fashae, K., et al., Fluoroquinolone-resistant enteric bacteria in SubSaharan Africa: clones, implications and research needs, Front. Microbiol., 2016, vol. 22, no. 7, p. 558. doi 10.3389/fmicb.2016.00558

19. Manzo, L.M., Issaka, B.B., Seidou, I., and Zanguina, J., Antibiotic resistance mechanisms focusing on quinolones resistance in Vibrio cholerae, Int. J. Infect., 2017, vol. 4, no. 3. e40622. doi 10.5812/iji.40622

20. Blackstone, G.M., Nordstrom, J.L., Bowen, M.D., et al., Use of a real time PCR assay for detection of the ctxA gene of Vibrio cholerae in an environmental survey of Mobile Bay, J. Microbiol. Methods, 2007, vol. 68, no. 2, pp. 254-259. doi 10.1016/j.mimet.2006.08.006

21. Kumar, P., Jain, M., Goel, A.K., et al., A large cholera outbreak due to a new cholera toxin variant of the Vibrio cholerae $\mathrm{O} 1 \mathrm{El}$ Tor biotype in Orissa, Eastern India, J. Med. Microbiol., 2009, vol. 58, pt. 2, pp. 234-238. doi 10.1099/jmm.0.002089-0

22. Hochhut, B., Lotfi, Y., Mazei, D., et al., Molecular analysis of antibiotic resistance gene clusters in Vibrio cholerae 0139 and 01 SXT Constins, Antimicrob. Agent Chemother., 2001, vol. 45, no. 11, pp. 2991-3000. doi 10.1128/aac.45.11.2991-3000.2001

23. Zadnova, S.P. and Smirnova, N.I., Detection of antibiotic resistance genes in Vibrio cholerae strains of serogroups $\mathrm{O} 1$ and O139, Zh. Mikrobiol. Epidemiol. Immunobiol., 2015, no. 3, pp. 3-10.

Translated by V. Mittova 